\title{
Presence of the Pacific oyster (Crassostrea gigas Thunberg, 1793) in the Black Sea
}

\author{
Mehmet AYDIN* Mustafa GÜL \\ Ordu University, Fatsa Faculty of Marine Science, Ordu 52400, Turkey.
}

How to cite: Aydin, M. \& Gül, M. (2021). Presence of the Pacific oyster (Crassostrea gigas Thunberg, 1793) in the Black Sea. J. Anatolian Env. and Anim. Sciences, 6(1), 14-17.

Atıf yapmak için: Aydin, M. \& Gül, M. (2021). Pasifik istiridyesinin (Crassostrea gigas Thunberg, 1793) Karadeniz’de varlığı. Anadolu Çev. ve Hay. Dergisi, 6(1), 14-17.

https://orcid.org/0000-0003-1163-6461 (iD) : https://orcid.org/0000-0002-2864-273X
*Corresponding author's: Mehmet AYDIN

Ordu University, Fatsa Faculty of Marine

Science, Ordu 52400, Turkey.

凶: maydin69@hotmail.com

\begin{abstract}
Pacific oyster (Crassostrea gigas), as an alien species to Black Sea ecosystem, is a highly commercial species with the highest production rate in aquaculture in the world. This species has been raised on the Crimean and Romanian Coasts since 1980s with reports of potentially breeding wild populations in those regions. However, the presence of this species on the Turkish coast of Black Sea is literally unknown. Therefore, here we investigated the occurrence and population density of the wild colonies of Pasific oyster on Ordu Coasts. We found that $C$. gigas has created breeding populations on the Turkish coasts with becoming the dominant species on some hard substrate including rocky bottoms and large rocks that were used for the fulfilment of the coastal regions to gain more land. Further, the population density was 94.58 ind. $/ \mathrm{m}^{2}$ with an average shell length of $3.33 \pm 0.724 \mathrm{~cm}$. Our results here showed that $C$. gigas has adapted to the Turkish coasts of Black Sea with creating breeding populations, therefore a management plan should be applied in order to reduce the potential influence of this species on the natural communities.
\end{abstract}

\section{Keywords: Black sea, invasive, pacific oyster, Crassostrea gigas.}

\section{Pasifik istiridyesinin (Crassostrea gigas Thunberg, 1793) Karadeniz'de varlığı}

*Sorumlu yazar:

Mehmet AYDIN

Ordu Üniversitesi, Fatsa Deniz Bilimleri

Fakültesi, Ordu 52400, Türkiye.

凶: maydin69@hotmail.com

\begin{abstract}
Öz: Pasifik istiridyesi (Crassostrea gigas) yüksek ekonomik değeri olan ve dünyada en çok üretimi yapılan türdür. Kırım ve Romanya kıyılarında 1980'li yıllarda kültür çalışmaları yapılmış ve bölgede doğal stokların ürediği rapor edilmiştir. Ancak, türün Karadeniz'in Türkiye kıyılarında varlığı bilinmemektedir. Bu çalışmada pasifik istiridyesinin Ordu sahillerinde varlığı, populasyon yoğunluğu ve boyutları araştırılmıştır. $C$. gigas türünün Türkiye sahillerinde üreyip populasyon oluşturduğu, sert zeminlerde, doğal kayalık bölgelerde ve dolgu alanlarında dominant tür haline geldiği belirlenmiştir. Ayrıca populasyon yoğunluğu 94,58 birey $/ \mathrm{m}^{2}$ olarak, ortalama kabuk boyu ise 3,33 $\pm 0,724 \mathrm{~cm}$ olarak hesaplanmıştır. Sonuç olarak, pasifik istiridyesinin Karadeniz' in Türkiye sahillerine adapte olduğu ve doğal bir populasyon oluşturduğu söylemek mümkündür. Ayrıca türün bölgedeki doğal stoklara etkisinin araştırılması için bir yönetim planının hazırlanması gerektiği düşünülmektedir.
\end{abstract}

Anahtar kelimeler: Karadeniz, istilac1, pasifik istiridyesi, Crassostrea gigas.

\section{INTRODUCTION}

The Pacific oyster, Crassostrea gigas (Thunberg, 1793 ) is a highly commercial Bivalvia species (Wolff \& Reise 2002; Batista et al., 2008). It is native to Japanese coast of Pacific Ocean; however, it is the most common aquaculture species in the world with high ability of adaptations to various environmental conditions (Shatkin et al., 1997; Ruesink et al., 2005). Pacific oyster has been introduced to more than seventy countries and has established breeding populations in seventeen of these (Ruesink et al., 2005). Aquaculture productions of this 
species started in 1920s in the USA and in 1966 in France. Further, Italy has the highest production and consumption rates of this species in Europe (FAO, 2018). Besides its high rate of production in aquaculture in different countries, it has been introduced to the new aquatic areas via unintentionally ships and intentionally shellfish farming. Both larvae and eggs in the ballast waters and the adults attached to the bottom of the ships have been unintentionally distributed globally (Schmidt et al., 2008; Keller et al., 2011; Pecarevic et al., 2013).

C. gigas was first introduced to the Black Sea in 1980 for aquacultural purposes on the Crimean coast (Zolotarev, 1996). Following to this first introduction, the species was reported in the natural areas in 1995 (Micu, 2004). The species was cultured between 2001- 2003 on the Romanian coasts (Zaharia \& Crivăţ, 2017). Pacific oyster has been reported in the natural areas out of the aquacultural areas in the Black Sea (Skolka \& Gomoiu, 2004) with rapid adaptations to the environmental conditions on the coast of Romania (Krapal et al., 2019). Additionally, Pacific oyster has been reported in the Sea of Marmara, Aegean and Mediterranean Seas (Acarli et al., 2017; Gökçek et al., 2020). However, bio-ecological characteristics including occurrence, distribution and reproduction etc. of Pacific oyster on the Turkish coast of Black Sea are still unknown. Therefore, occurrence, density and size-age distribution of the wild colonies of this species have been investigated. Additionally, the potential relationships of Pacific oyster with other native and none native species in the Black Sea were discussed.

\section{MATERIAL AND METHOD}

This study was conducted on the Ordu Coast of Southern Black Sea in July $2020\left(41^{\circ} 06{ }^{\prime} 57.79^{\prime \prime N}\right.$ $37^{\circ} 20^{\prime} 51.26^{\prime \prime} \mathrm{E}-41^{\circ} 02^{\prime} 02.42^{\prime \prime N} 37^{\circ} 30^{\prime} 08.88^{\prime \prime} \mathrm{E}$ ) (Figure 1).

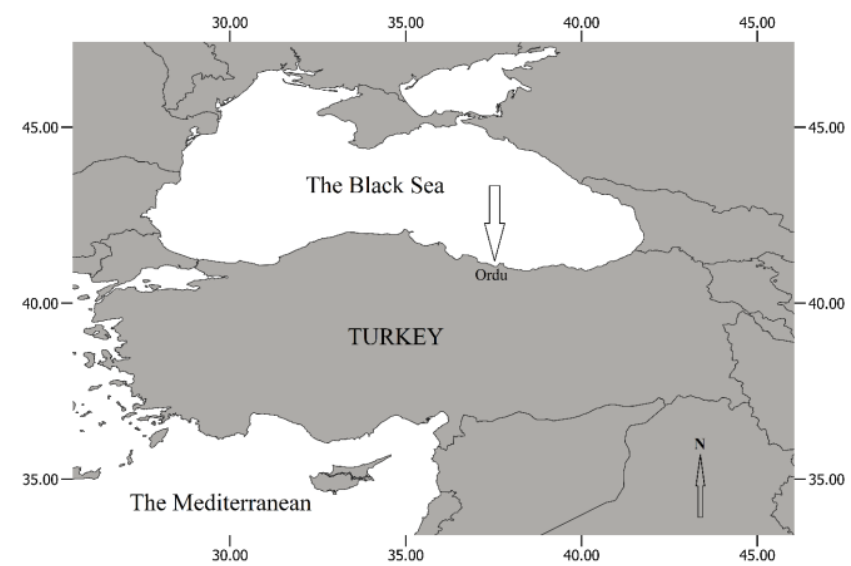

Figure 1. Sampled area.

We investigated the occurrence and density of Pacific oyster at 5 sites via a total of 15 times SCUBA diving on 2 consecutive days. At each site, we sampled $4800 \mathrm{~cm}^{2}$ of benthic habitat in three quadrats $(40 \times 40 \mathrm{~cm})$ from $0 \mathrm{~m}$ to $3 \mathrm{~m}$ at depth. We also photographed each quadrat for further investigations (Figure 2)

For species identification, we collected a few individuals from each quadrat and moved to the laboratory in which species identification was made using morphological characteristics (Lucas, 1982; NOBANIS, 2020; Poppe \& Goto, 2000). Following this, we determined the size distributions of the individuals observed in quadrats using ImageJ (with 64-bit Java 1.8.0_152) (Schneider et al., 2012). Since the length and the width of the individuals vary independently between individuals, we used body surface area as size variation of the oysters (length $\mathrm{X}$ width).

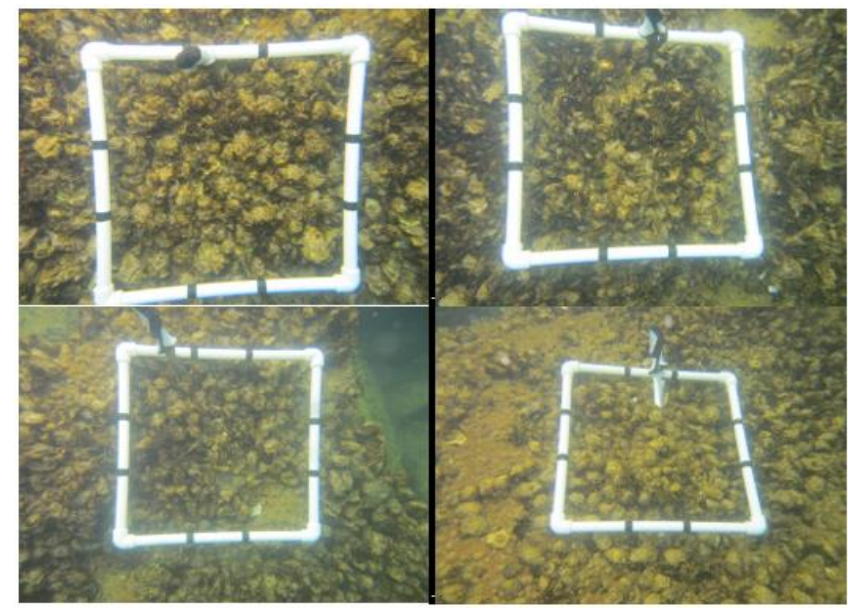

Figure 2. Quadrat sampled of different 4 site in Ordu (southern Black Sea).

\section{RESULTS}

We determined that Pacific oyster was the dominant species both on the large rocks used for land fulfilment and on the natural substrate on the coast (Figure $3)$.

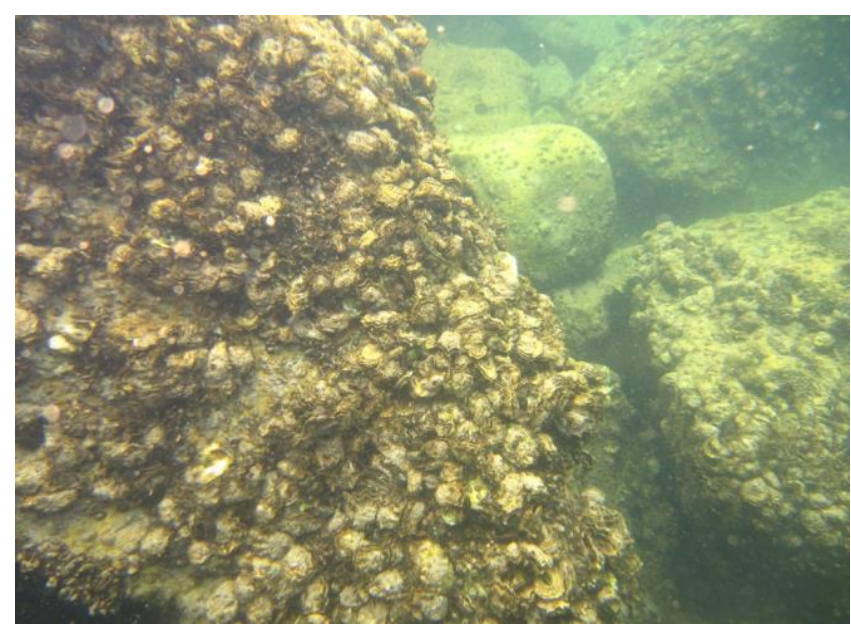

Figure 3. Crassostrea gigas habitat from the Black Sea littoral Turkey. 
We further observed that Pacific oyster share the same environment with other species on the Turkish coast of Black Sea. Specifically, Mediterranean mussel (Mytilus galloprovincialis) and Pacific oyster were mostly found in the same quadrat (Figure 4). Additionally, Patella species and rapa whelk (Rapana venosa) were evident in a few quadrats.

We examined a total of 227 oysters and the average length was found to be $3.33 \pm 0.724 \mathrm{~cm}$ (Min: $0.967 \mathrm{~cm}$-Max: $6.538 \mathrm{~cm}$ ) (Table 1).

We further observed that some shells were just opened and the meat of the oysters were removed, suggesting that Eurasian otter was feeding on this species in the region.

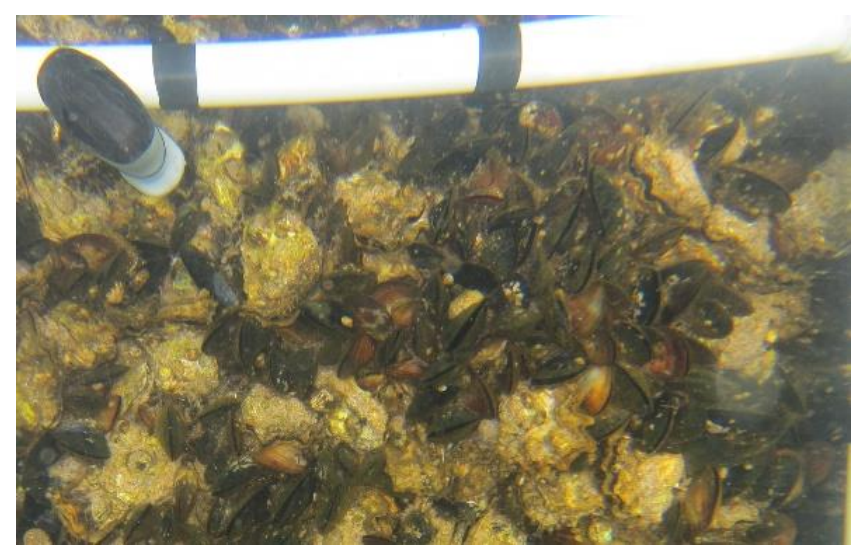

Figure 4. Mediterranean mussel and pacific oyster on the same habitat.

Table1. Crassostrea gigas density and morphometry in the Fatsa Region.

\begin{tabular}{lccccc}
\hline & Locality 1 & Locality 2 & Locality 3 & Locality 4 & Locality 5 \\
\hline Scaned Area $\left(\mathrm{cm}^{2}\right)$ & 4800 & 4800 & 4800 & 4800 & 3800 \\
Density (individual) & 53 & 66 & $3.40 \pm 1.083$ & $3.03 \pm 1.062$ & $3.51 \pm 1.022$ \\
Mean Length $(\mathrm{cm})$ & $3.56 \pm 0.794$ & $2.75 \pm 0.982$ & $1.95 \pm 0.656$ & $3.00 \pm \pm 0.752$ & $2.58 \pm 0.653$ \\
Mean Width $(\mathrm{cm})$ & $2.51 \pm 0.663$ & $9.26 \pm 4.276$ & $6.42 \pm 4.594$ & $9.48 \pm 4.663$ \\
Surface area of shell $\left(\mathrm{cm}^{2}\right)$ & $9.19 \pm 4.144$ & & & $6.61 \pm 3.203$ \\
\hline
\end{tabular}

\section{DISCUSSION}

During SCUBA diving operations with scientific and recreational purposes, a rapid increase in the abundance of Pasific oyster has been observed (Dr. Aydın, personal observation), suggesting the results from the potential arrival of the larvae and/or eggs in the ballast water and/or adults attached to the bottom of the ships. Further, Pasific oyster is the dominant species in the habitats that has been observed. Similarly, wild populations of Pacific oyster on the Romanian coasts of the Black Sea have been reported (Krapal et al., 2019).

Different studies investigated the size-age relationship of Pasific oyster in different regions in the world. The average size (e.g. shell length) for each age class found to be as $46 \mathrm{~mm}$ for the $1^{\text {st }}$ year, $72.1 \mathrm{~mm}$ for the $2^{\text {nd }}$ year, and $91.6 \mathrm{~mm}$ for the $3^{\text {rd }}$ year (Diederich, 2006; Cardoso et al., 2007; Christensen \& Elmedal, 2007; Wang et al., 2007; Walles et al., 2015). Considering the average shell length for the given age classes of the oysters found in those studies, the population on the Ordu Coast comprises mostly young individuals with an average shell length of $3.3 \mathrm{~cm}$. However, this inference should cautiously be accepted, since the growth may differ across habitats and regions.

C. gigas has the highest production rate among the aquaculture species due to its rapid and high capacity of adaptation and high reproduction abilities (Shatkin et al., 1997; Ruesink et al., 2005). The species reproduces at 18 ${ }^{\circ} \mathrm{C}$ (Enríquez-Díaz et al., 2009). The average water temperatures in the Black Sea reach these temperature values around in June, suggesting that reproduction starts in June in this region (MGM, 2020).

In this study, the wild colony of Pasific oyster in the southern Black Sea has been detected. In addition, this study indicates Pasific oyster is well adapted to the ecosystem of the southern Black Sea and suggests that they formed a stock in the southern Black Sea.

\section{REFERENCES}

Acarli, S., Vural, P. \& Gündüz. F. (2017). Meat yield and condition index of invasive species Pacific oyster (Crassostrea gigas, Thunberg 1793) in Bandirma Bay (Marmara Sea, Turkey). International Iskenderun Bay Symposium. 11-13 October 2017. İskenderun, Turkey. 120 pp.

Batista, F.M., Ben-Hamadou, R., Fonseca, V.G., Taris, N., Ruano. F., Reis-Henriques, M.A. \& Boudry, P. (2008). Comparative study of shell shape and muscle scar pigmentation in the closely related cupped oysters Crassostrea angulate, $C$. gigas and their reciprocal hybrids. Aquatic Living Resources, 21, 31-38. DOI: 10.1051/alr:2008019

Cardoso, J.F.M.F., Langlet, D., Loff, J.F., Martins, A.R., Witte, J.I.J., Santos, P.T. \& van der Veer, H.W. (2007). Spatial variability in growth and reproduction of the Pacific oyster Crassostrea gigas (Thunberg. 1793) along the west European coast. Journal of Sea Research, 57, 303-315.

Christensen, H.T. \& Elmedal, I. (2007). Den invasive stillehavsøsters, Crassostrea gigas. I Limfjorden. inddragelse af borgere og interessenter i forslag til en forvaltningsplan. p. 154. Limfjorden. ConchBooks. Hackenheim. 221 pp. 
Diederich, S. (2006). High survival and growth rates of introduced Pacific oysters may cause restrictions on habitat use by native mussels in the Wadden Sea. Journal of Experimental Marine Biology and Ecology, 328, 211-227.

Enríquez-Díaz, M., Pouvreau, S., Chávez-Villalba, J. \& Le Pennec, M. (2009). Gametogenesis, reproductive investment, and spawning behavior of the Pacific giant oyster Crassostrea gigas: evidence of an environment-dependent strategy. Aquaculture International, 17(5), 491.

FAO. (2018). The state of world fisheries and aquaculture 2018. Meeting the sustainable development goals. Rome.

Gökçek, E.Ö., Acarli, S., Karahan, B., Vural, P. \& Baştanlar, E.K. (2020). First molecular record of the alien species Pacific oyster (Crassostrea gigas, Thunberg 1793) in the Marmara Sea. Turkey. Marine Science and Technology Bulletin, 9, 23-31. DOI: 10.33714/masteb.668529

Keller, R.P., Drake, J.M., Drew, M.B. \& Lodge, D.M. (2011). Linking environmental conditions and ship movements to estimate invasive species transport across the global shipping network. Diversity and Distributions, 17, 93-102.

Krapal, A.M., Ioniţă, M., Caplan, M. \& BuhaciucIoniţă, E. (2019). Wild Pacific oyster Magallana gigas (Thunberg, 1793) populations in Romanian Black Sea waters-friend or foe? Travaux $d u$ Muséum National d'Histoire Naturelle "Grigore Antipa”, 62, 175-183. DOI: 10.3897/travaux.62.e49074

Lucas, M. (1982). The genus Crassostrea in Europe. La Conchiglia 14, 18-19.

MGM. (2020). Distribution of sea water temperatures in the Black Sea. Reports of the Ministry of Agriculture and Forestry General Directorate of Meteorology. https://www.mgm.gov.tr/.

Micu, D. (2004). Annotated checklist of the marine Mollusca from the Romanian Black Sea. International Workshop on the Black Sea Benthos. 18-23 April 2004. Istanbul. Turkey. pp. 89-152.

NOBANIS. (2020). Fact sheet Crassostrea gigas. Available from http://www.NOBANIS.org. Data of Access, 20/07/2020.

Pecarevic, M., Mikus, J., Bratos, Cetinic, A., Dulcic, J. \& Calic, M. (2013). Introduced marine species in Croatian waters (Eastern Adriatic Sea). Mediterranean Marine Science, 14(1), 224-237. DOI: $10.12681 / \mathrm{mms} .383$

Poppe, G. \& Goto, Y. (2000). European Seashells Vol. II (Scaphopoda. Bivalvia. Cefalopoda). Press Constanța. 185 pp. [in Romanian].

Ruesink, J.L., Lenihan, H.S., Trimble, A.C., Heiman, K.W., Micheli, F., Byers, J.E. \& Kay, M.C. (2005) Introduction of non-native oysters: Ecosystem effects and restoration implications. Annual Review of Ecology. Evolution and Systematics, 36, 643-689.
Schmidt, A., Wehrmann, A. \& Dittmann, S. (2008). Population dynamics of the invasive Pacific oyster Crassostrea gigas during the early stages of an outbreak in the Wadden Sea (Germany). Helgoland Marine Research, 62(4), 367-376. Doi: 10.1007/s10152-008-0125-8

Schneider, C.A., Rasband, W.S. \& Eliceire, K.W. (2012). NIH image to ImageJ: 25 years of image analysis. Nature Methods, 9, 671-675.

Shatkin, G., Shumway, S.E. \& Hawes. R. (1997). Considerations regarding the possible introduction of the pacific oyster (Crassostrea gigas) to the Gulf of Maine: a review of global experience. Journal of Shellfish Research, 16(2), 463-477.

Skolka, M. \& Gomoiu, M.T. (2004). Specii invazive în Marea Neagră. Impactul ecologic al pătrunderii de noi specii în ecosistemele acvatice. Ovidius University Press Constanţ. 180p.

Walles, B., Mann, R., Ysebaert, T., Troost, K., Herman, P.M.J. \& Smaal, A.C. (2015). Demography of the ecosystem engineer Crassostrea gigas related to vertical reef accretion and reef persistence. Estuarine Coastal and Shelf Science, 54, 224-233. DOI: 10.1016/j.ecss.2015.01.006

Wang, J., Christoffersen, K., Buck, S., Tao, Y. \& Hansen, B.W. (2007). The Pacific Oyster (Crassostrea gigas) in the Isefjord. Denmark, Roskilde University, Department of Environmental, Social and Spacial Change. Roskilde. p. 49.

Wolff, W.J. \& Reise, K. (2002). Oyster imports as a vector for the introduction of alien species into northern and western European coastal waters. In Invasive aquatic species of Europe. Distribution impacts and management (pp. 193-205). Springer, Dordrecht.

Zaharia, T. \& Crivăţ, M. (2017). Creşterea dirijată a stridiei japoneze (Crassostrea gigas) la litoralul românesc [Directed growth of the Japanese oyster (Crassostrea gigas) in the Romanian littoral zone]. In: Zaharia, T., Niţă, V.N. \& Nenciu, M.I. (Eds) Bazele acvaculturii marine in România [The basics of marine aquaculture in Romania]. CD PRESS. Bucureşti. 28-49. [in Romanian].

Zolotarev, V. (1996). The Black Sea ecosystem changes related to the introduction of new mollusc species. Marine Ecology, 17, 227-236. 